\title{
Dealing with Metric Unit Conversion: An Examination of Prospective Science Teachers' Knowledge of and Difficulties with Conversion
}

\author{
Emrah Oguzhan Dincer, Aslihan Osmanoglu* \\ Department of Mathematics and Science Education, Faculty of Education, Trakya University, Edirne, Turkey \\ *Corresponding Author: aslihanosmanoglu@trakya.edu.tr
}

\section{ABSTRACT}

The aim of this study was to examine prospective science teachers' knowledge of and difficulties with the metric unit conversion. The participants of the study were 73 prospective science teachers. In this qualitative study, a measurement test with 14 questions was administered to the participants to examine their knowledge of and difficulties with unit conversion. The questions of the test were related to metric measurement units for length, area, volume, and mass, as well as to the knowledge of the approximate size of a body and some uses of metric units. For the first 11 questions, participants' answers were evaluated as right or wrong. To examine the reasons lying behind their difficulties, their explanations on the past three open-ended questions were analyzed. The findings indicated that prospective teachers' performance on unit conversion was not satisfying in general, and their major difficulties were mainly related to the conversion from gram into microgram, $\mathrm{mg}$ into $\mathrm{g}, \mathrm{ml}$ into $\mathrm{cm}^{3}, \mathrm{dm}^{3}$ into $\mathrm{mm}^{3}$, gigameter into nanometer, $\mathrm{mm}^{2}$ into $\mathrm{m}^{2}$, and determining the relationship between centigram and dekagram. The implications for the field are discussed in light of the related literature.

KEY WORDS: unit conversion; knowledge of unit conversion; difficulties with unit conversion; metric system; prospective science teachers

\section{INTRODUCTION}

\section{Measurement}

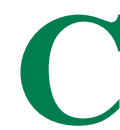

heng (1976) defined a measurement system as a tool for communication and added that this system was necessary for people to communicate in business, industry, and/or daily life. In 1960, the International System of Units (SI) was accepted as a formal measurement system to ease this communication (Koray et al., 2005). SI is the modern metric system of measurement (Harmon, 1984; Thompson and Taylor, 2008), and it is the most common unit system used in measurement (Leroy, 1973). In this system, seven main units were defined: Length, mass, time, electric current, thermodynamic temperature, luminous intensity, and amount of substance (Thompson and Taylor, 2008). SI is directly related to MKS (meter-kilogram-second) system (Harmon, 1984) while it treats the conversions across categories differently than the traditional metric system as it does not deal with the powers of 10 through SI prefixes; instead, the derived units are based on SI main units (Ludwig, 2016).

Leroy (1973) suggests that the metric system is a logical system as its standards are based on natural phenomena, and the conversion factors are powers of 10 . Knowing and converting between units are an ability needed to be comprehended by students (Ford and Gilbert, 2013). The Common Core State Standards for Mathematics (CCSS, 2011) also underlines the importance of this ability. Hallagan (2013) adds that learning the metric system is among the main concerns of mathematics and science curriculum.

\section{Essential Skills and Unit Conversion}

"Physical world was established by symbols and units" (Uhden and Pospiech, 2009. p. 30). Science - especially mathematics and physics - come to the fore when symbols and units are concerned. Research indicates that to be able to do physics and solve problems in physics, a strong mathematical background is vital as mathematics is a prerequisite for the majority of physics courses (Nguyen, 2011). Mathematics and physics have several common concepts including unit conversion to be able to do science and make sense of the world.

Essential skills are explained as prerequisite skills for university-level courses, and they cover metric prefixes and conversions (Mikula and Heckler, 2013). In their study with engineering students, Mikula and Heckler (2013) indicated that although they were already supposed to comprehend them, students had difficulties with such essential skills. More specifically, while they were expected to have sufficient skills to convert micrograms to kilograms and/or centimeters to nanometers, etc., it was seen that many students lacked this understanding. The researchers claimed that engineering students' low performance was worrisome, as they needed to use metric conversions routinely while solving problems in engineering. The researchers underlined that as a prerequisite for problem-solving, students should have a high level of 
accuracy with these skills, as when their accuracy decreases below $80 \%$, it gets harder to ensure student success.

Several other studies in the literature indicate that students have difficulty with the metric unit conversion. In a recent study by Cebesoy and Yeniterzi (2016), it was found that while solving physics problems related to force and motion unit, $7^{\text {th }}$ grade students mathematically struggled with unit conversion. In another study by Bagno et al. (2008), manipulating units were among students' difficulties in problem-solving. In Aydın's (2011) study, $1^{\text {st }}$-year science teaching students made mathematical mistakes in a General Chemistry II course as they had a deficient knowledge of mathematics including unit conversion. More specifically, it was identified that some of the participants made mistakes in converting milligram into gram while trying to solve a proportion/ratio problem. Birinci and Pirasa (2010) also stated that rather than making mistakes related to chemistry content, the participants in their study mostly made mathematical mistakes while answering chemistry questions as they had a lack of knowledge of mathematical concepts including unit conversion. Similar to Aydin's (2011) study findings, the students in their study also had difficulty with converting milligram into gram. The researchers concluded that science teaching students had a deficient knowledge of unit conversion and such deficiency risks their science literacy skills.

In another study by Gilman (2013) exploring the students' misconceptions about metric conversion with the difficulties regarding unit estimation, the researcher concluded that no matter what the direction of the conversion was, the students had difficulty with converting units. She noted, however, that students were more successful in converting length units rather than volume and capacity, as well as they were more accurate with units smaller than a meter.

Hallagan (2013) also noted that in her study, prospective teachers in the North-Eastern United States were only able to solve conversion problems using the metric system in the one direction they learned in high school. She highlighted, those prospective teachers had more difficulties when they encountered prefixes such as Nano and Giga, because they could not rely on their memorized prefixes. Hallagan (2013) underlined the necessity of the use of multiple methods to be able to solve the problems with confidence and to verify the solutions. She concluded that within the metric system, studying prospective teachers' solution methods of conversion problems might be a good step to achieve this.

At this point, it should be noted that - as a common language - the comprehension of SI unit system starting from early grades is necessary (Koray et al., 2005), and as Delgado et al. (2015) argued, incorporation of nanoscale concepts in science education is vital. When it is taken into account that the ability to comprehend unit conversion is needed for a strong scientific base for students (especially for science and engineering students), the importance of its conception might be better understood (Koray et al., 2005).

\section{Integration of Science and Mathematics}

As Lehavi et al. (2017) pointed out, the topic of physicsmathematics interrelations has been the focus of attention in physics education research. Among such studies, some of them refer to the university level students' difficulties in conceptually using mathematical knowledge in physics (Çorlu and Çorlu, 2012; Rebmann and Viennot, 1994; Meltzer, 2002; Redish, 2005; Tuminaro and Redish, 2007; Uhden et al., 2012) while others focus on teachers' understanding of mathematical concepts in science and/or physics education (Oktay et al., 2014).

Reviewing the literature on the integration of science and mathematics, Kurt and Pehlivan (2013) summarized the definitions of, methods, and models with regard to the integration of science and mathematics. Accordingly, there are several approaches to science and mathematics integration with different categorizations. Among those, the model by Lonning and DeFranco (1997) suggested that the interaction between science and mathematics might be explained under different categories as independent mathematics, mathematics focus (with science concepts in support), balanced mathematics and science, science focus (with mathematics concepts in support), and independent science. No matter what the type of the integration is, the fact is that the fields of mathematics and physics share several common concepts to make sense of the world, and mathematical background is vital for doing physics (Nguyen, 2011). Redish (2017) underlined that both the European Union and US biology community identified mathematics as a critical scientific competency. Redish (2017) added that it is vital to understand the role of mathematics in physics to improve physics instruction. Greca and de Ataíde (2017) also noted that helping students understand the relation between physics and mathematics during learning might lead to a better understanding of the importance of the use of mathematical models in physics. Uhden et al. (2012) further added that:

Mathematics is often seen as a tool for calculation, which hinders a conceptual understanding of physical principles. However, the role of mathematics cannot be reduced to this technical aspect. Hence, instead of putting mathematics away we delve into the nature of physical science to reveal the strong conceptual relationship between mathematics and physics. Moreover, we suggest that, for both prospective teaching and further research, a focus on deeply exploring such interdependency can significantly improve the understanding of physics (p. 485).

Referring to previous work by Pietrocola (2010) and Feynman (1989), Greca and de Ataíde (2017) emphasized that mathematics were the language of physical knowledge. Thus, to build this knowledge, mathematics should be an important part of physics learning, not only as an instrument but also as a concept to be understood. In his study, Meltzer (2002) indicated that students' initial mathematical skills were significantly correlated to their learning gains in physics. 
Regarding the interaction between science and mathematics, Science, Technology, Engineering, and Mathematics (STEM) education programs has been drawing attention among OECD countries since the 1990s (Blackley and Howell, 2015; Chalmers et al., 2017). In those programs, students found a chance to apply different concepts in multidisciplinary contexts while connecting schoolwork to the real world (Chalmers et al., 2017). Cooke and Walker (2015) reported that STEM education might be a way to enhance student understanding in both science and mathematics through making learning a meaningful experience. The researchers indicate that to integrate mathematics with the other areas underlined in STEM education, prospective teachers "... in all phases of schooling must be prepared to teach content in a knowledgeable, inspirational, and confident manner" (Cooke and Walker, 2015. p. 35). Therefore, the importance of investigating prospective teachers' mathematical understanding of unit conversion as a critical topic in physics comes to the fore.

\section{Purpose and Research Questions}

Considering that understanding the concept of unit conversion is a prerequisite for doing science and many students have difficulties with converting metric units, it is vital to examine prospective teachers' knowledge of and difficulties with unit conversion to be able to make suggestions for educators. The research questions to investigate were:

1. To what extent can prospective science teachers convert metric units?

2. What are the prospective science teachers' major difficulties with unit conversion?

\section{METHOD}

The study was qualitative in nature as the aim was to understand the patterns characterizing the data as well as the participants' understanding of the phenomenon (Merriam, 2009). Below, the participants, data collection, and data analysis processes are explained.

\section{Participants}

This study was conducted with 73 prospective science teachers (55 female and 18 male) who were in their past year of study and taking the Astronomy course from the first researcher in one of the western universities in Turkey in 2016-2017 academic year. The prospective science teachers were studying to teach $5^{\text {th }}-8^{\text {th }}$-grade students (students aged $10-14$ years old). During the study, the prospective teachers were already expected to be proficient in unit conversion. As part of their study, they had already taken courses such as General Physics I-based on mechanics, General Physics II-based on electric, and General Physics III-based on thermodynamics and optics, Introduction to Modern Physics, and their related laboratories during their initial teacher education. In those courses, they were expected to have used their knowledge of unit conversion. It should also be noted that students in Turkey receive instruction on metric units starting from the $2^{\text {nd }}$ grade (students aged 7-8) and unit conversion starting from the $3^{\text {rd }}$ grade in mathematics classes (TTKB, 2017).

\section{Data Collection}

For the data collection, a measurement test with 14 questions was prepared by the researchers drawn from the literature (Butterfield et al., 2011; Ford and Gilbert, 2013; Gilman, 2013; Hallagan, 2013; Livy and Vale, 2011). The first 11 questions of the measurement test $(1,2,3,4 a-b, 5,6,7,8 a-b-c, 9,10$, and $11 \mathrm{a}-\mathrm{b})$ consisted of questions about conversions within metric measurement units for length, area, volume, mass, as well as the knowledge of approximate size of a body and some uses of metric units (Appendix 1). The other remaining three open-ended questions (12-14) aimed to determine whether and what kind of difficulties the participants had on unit conversion. The test was administered to the participants at the end of the semester to examine what they knew about unit conversion. The participants volunteered to participate in the study. They were required to provide explanations on their answers for each question.

\section{Data Analysis}

In the data analysis process, content analysis technique was employed (Neuendorf, 2002). To answer the first research question, participants' answers to the first 11 questions were evaluated as either right (1) or wrong (0). The researchers individually coded the participants' answers first, and then came together and compared their coding. After identifying small mismatches, they reached a consensus.

To answer the second research question, participants' answers to the past three open-ended questions were examined by the researchers. More specifically, to examine the reasons lying behind prospective teachers' difficulties with unit conversion, an analysis of their explanations for each question was conducted. The researchers first individually coded the participants' explanations by open-coding technique, and after comparing the coding, they discussed them until they reached a consensus. Accordingly, participants' answers were coded as "yes," "sometimes," "no," or "no answer" in the $12^{\text {th }}$ question; and their answers were ranked from the highest to the lowest percentage in the $13^{\text {th }}$ and $14^{\text {th }}$ questions. To understand participants' difficulties with unit conversions as well as to strengthen the findings, direct quotations selected from their explanations were provided.

\section{Findings}

The aim of this study was to understand the extent that the prospective science teachers can convert metric units and identify their major difficulties with unit conversion. Below, the findings are provided under two sub-titles regarding the research questions.

\section{To What Extent Can the Prospective Science Teachers Convert Metric Units?}

For the first research question, data analysis indicated that the unit conversion performance of the prospective teachers was not generally satisfactory. The related frequencies with the percentages for each question are presented in Table 1.

Accordingly, the number of the prospective teachers giving correct answers to the conversion questions was quite low. 


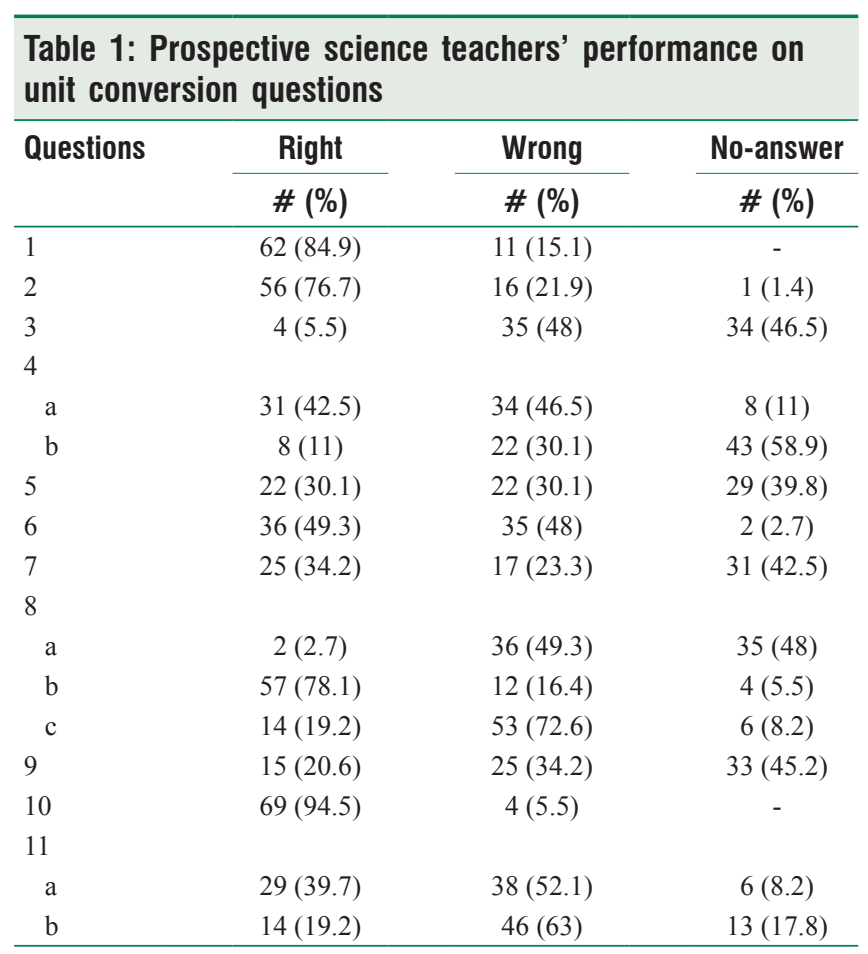

Table 1 shows that only in questions $1,2,8 b$, and 10 were a majority of the participants able to provide the right answers. Besides, the wrong answers, the findings also revealed that the percentages of the participants who could not provide an answer to the questions were high. Below, the findings are examined through individual questions. It should be noted that each participant was numbered, and the direct quotations from the participants' explanations are provided with the number of the participants as $\mathrm{P} \#$ below.

In the $1^{\text {st }}$ question (having the second most successful performance after the $10^{\text {th }}$ question), the majority of the participants were able to convert $\mathrm{cm}$ into $\mathrm{mm}(84.9 \%)$. The percentage of the wrong answers was $15.1 \%$. The analysis of the participants' explanations to their answers revealed that prospective teachers were aware that a $\mathrm{cm}$ was 10 times bigger than a mm, so they needed a larger number. Below, some examples from the participants' explanations are provided:

As $\mathrm{cm}>\mathrm{mm}$, we should add a zero $(\mathrm{P} \# 4)$

$1 \mathrm{~cm}$ is equal to $10 \mathrm{~mm}$. Hence, $50 \mathrm{~cm} \times 10 \mathrm{~mm}=500 \mathrm{~mm}$ (P\#16)

As we go down through the units ( $m, d m, c m, m m)$, we add a zero beside the number. Hence, as $1 \mathrm{~cm}=10 \mathrm{~mm}$, then $50 \mathrm{~cm}=500 \mathrm{~mm}(\mathrm{P} \# 18)$

While the majority of the participants' explanations were like the above, there were some wrong answers given to this question. An example:

$50 \times 100=5000 \mathrm{~mm}$, because they decrease and increase 100 times $(\mathrm{P} \# 31)$

From here, we can deduce that some of the participants did not know that the length units get 10 times bigger when converting from smaller to larger units.
In the $2^{\text {nd }}$ question, the participants were asked to convert $\mathrm{mm}$ into $\mathrm{km}$, it was seen that $76.7 \%$ of them were able to provide correct answer. The percentage of wrong answers for this question was $21.9 \%$. When their explanations were examined, it was seen how some of the participants reached $\mathrm{km}$ from $\mathrm{mm}$ :

$1 \mathrm{~km}$ is equal to $1.000 .000 \mathrm{~mm}$. Then, $1 / 1.000 .000$ of $450.000 .000 \mathrm{~mm}$ is $450 \mathrm{~km}(\mathrm{P} \# 51)$

$1 \mathrm{~km}=1000 \mathrm{~m}$ and $1 \mathrm{~m}=1000 \mathrm{~mm}$. Then, $1 \mathrm{~km}=1.000 .000 \mathrm{~mm}$, and thus 45,00,00,000 $\mathrm{mm}=450 \mathrm{~km}(\mathrm{P} \# 63)$

It was seen that some others preferred to identify each unit step by step. In the below example, participant\#72 provided a table for her/his answer:

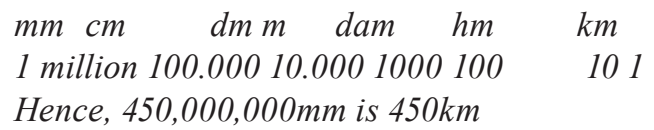

The $3^{\text {rd }}$ question asked the participants to convert gigameter into nanometer and was among the most difficult questions for the participants. Accordingly, the percentage of the correct answers was only $5.5 \%$. Wrong answers and no-answers shared similar percentages (48\% and 46.5\%, respectively). Giving some examples of the wrong answers might shed some light on the reasons why these participants struggled with this conversion:

$$
\begin{aligned}
& 25 \mathrm{Gm}=25 \times 10^{-18} \mathrm{~nm}(\mathrm{P} \# 14) \\
& 25 \mathrm{Gm}=25 \cdot 10^{6} \cdot 10^{-9} \mathrm{~nm}(\mathrm{P} \# 28) \\
& 25 \mathrm{Gm}=25.10^{-18} \mathrm{~nm} \text {. Nanometer is equal to } 10^{-9} \mathrm{~m} \text {, and } \\
& \text { there are } 18 \text { zeros from positive to negative. Gigameter } \\
& \text { is equal to } 10^{9} \mathrm{~m}(\mathrm{P} \# 46)
\end{aligned}
$$

From the above examples, we see that the participants had difficulties with deciding on the direction of the conversion (P\#14), knowing the relation between gigameter and meter, and deciding on the direction while converting meter into nanometer ( $\mathrm{P} \# 28$ ), and converting between the units because of mathematical difficulties while their logic was accurate $(\mathrm{P} \# 46)$.

The $4^{\text {th }}$ question had two sub-questions. In the first subquestion, participants were asked to convert $\mathrm{mg}$ into $\mathrm{g}$ and $\mathrm{ml}$ into 1 , and then take the ratio of these values and calculate the value of density in $\mathrm{g} / \mathrm{l}$. The findings revealed that $42.5 \%$ of the participants were able to make these conversions and then calculate the density correctly. In the second sub-question, the participants were asked to determine the value of this density in terms of $\mathrm{g} / \mathrm{cm}^{3}$. Accordingly, it was assessed whether they knew the relation between liter and $\mathrm{m}^{3}$, and thus whether $\mathrm{ml}$ was equal to $\mathrm{cm}^{3}$. Only $11 \%$ of the participants provided correct answers to this sub-question while $58.9 \%$ of them could not provide any answer at all. This question had the highest noanswer percentage with more than half of the participants not able to answer this question. Below, there are two examples from the participants' answers to these sub-questions:

$$
\begin{aligned}
& \text { [for } 4 a] V=50 \mathrm{ml}=0.05 \mathrm{l}, \mathrm{m}=450 \mathrm{mg}=0.45 \mathrm{~g}, \text { and so } \\
& d=m / V=0.45 / 0.05=9 \mathrm{~g} / \mathrm{l} \\
& {[\text { for } 4 \mathrm{~b}] \mathrm{ll}=1000 \mathrm{~cm}^{3}, 0.05 \mathrm{l}=50 \mathrm{~cm}^{3}, \text { so } d=\mathrm{m} / \mathrm{V}=} \\
& 0.009 \mathrm{~g} / \mathrm{cm}^{3}(\mathrm{P} \# 18) \\
& {[\text { for } 4 a] d=m / V=0.45 \mathrm{~g} / 0.05 \mathrm{l}=9 \mathrm{~g} / \mathrm{l}} \\
& {[\text { for } 4 b] 1 \mathrm{dm}^{3}=1 \mathrm{l}, 50 \mathrm{ml}=0.05 \mathrm{l}=50 \mathrm{~cm}^{3}, d=\mathrm{m} / V=}
\end{aligned}
$$




\section{$0.45 \mathrm{~g} / 50 \mathrm{~cm}^{3}=0.009 \mathrm{~g} / \mathrm{cm}^{3}(\mathrm{P} \# 25)$}

The above correct answers reveal that these participants were aware of the relationship between $\mathrm{ml}$ and liter as well as $\mathrm{mg}$ and $\mathrm{g}$, and were able to get the correct answer in $\mathrm{g} / \mathrm{l}$ (P\#18), and were able to find the correct answer in $\mathrm{g} / \mathrm{cm}^{3}$ as they knew that $1 \mathrm{~L}$ was equal to $1 \mathrm{dm}^{3}$ and thus equal to $1000 \mathrm{~cm}^{3}$ (P\#25). On the contrary, the below answers reveal that some of the prospective science teachers did not know that $\mathrm{ml}$ was equal to $\mathrm{cm}^{3}$ while some of them did not know the relationship between either $\mathrm{mg}$ and $\mathrm{g}$ or $\mathrm{ml}$ and 1 , and some others could not correctly decide on the direction of the conversions:

$$
\begin{aligned}
& V=50 \mathrm{ml}=5 \mathrm{~cm}^{3}, m=450 \mathrm{mg}=0.45 \mathrm{~g}, d=0.9 \mathrm{~g} / \mathrm{cm}^{3} \\
& (\mathrm{P} \# 29) \\
& m=450 \mathrm{mg}=45 \times 10^{-5} \mathrm{~g}, V=50 \mathrm{ml}=5 \times 10^{-5} l(\mathrm{P} \# 19) \\
& 50 \mathrm{ml}=0.5 \mathrm{l}, 100 \mathrm{mg}=1 \mathrm{~g}, 450 \mathrm{mg}=45 \mathrm{~g}(\mathrm{P} \# 37) \\
& 50 \mathrm{ml}=5000 \mathrm{~L}, d=m / V=45000 \mathrm{~g} / 5000 \mathrm{~L}=9 \mathrm{~g} / \mathrm{L}(\mathrm{P} \# 48)
\end{aligned}
$$

In the $5^{\text {th }}$ and also the $9^{\text {th }}$ question, the participants were asked about the relationship between centigram and dekagram. The only difference between these two questions was that in the $9^{\text {th }}$ question, the value given in the $5^{\text {th }}$ question was provided in the exponential form. The percentages of the correct answers were $30.1 \%$ and $20.6 \%$, respectively, meaning that some of the participants who correctly answered the $5^{\text {th }}$ question could not correctly answer it when the value was provided in the exponential form. Below, there is one correct and one wrong answer from the participants' solutions to the $5^{\text {th }}$ question:

cg dg g dag, and we divide them to 10 in each step (P\#39)

It was 10 times twice, so I deleted 4 zeros (P\#16)

Parallel to the $5^{\text {th }}$ and $9^{\text {th }}$ questions, in the $7^{\text {th }}$ question, the participants were asked to convert dekagram into centigram. The percentage of the correct answers was $34.2 \%$ for this question. From here, it was seen that the percentage of the correct answers was somewhat higher for the conversion from the larger units into smaller units when compared to the $5^{\text {th }}$ and $9^{\text {th }}$ questions (from dekagram into centigram) than that of the opposite.

In the $6^{\text {th }}$ question, the participants were asked to convert $\mathrm{cm}^{2}$ into $\mathrm{m}^{2}$. It was seen that the percentages of correct and wrong answers were quite similar ( $49.3 \%$ and $48 \%$, respectively). Below, there are two examples of wrong answers from the participants' explanations:

$$
\begin{aligned}
& 1 \mathrm{~m}=100 \mathrm{~cm}, 3200 / 100=32,3200 \mathrm{~cm}^{2}=32 \mathrm{~m}^{2}(\mathrm{P} \# 5) \\
& 3200 \mathrm{~cm}^{2}=320000 \mathrm{~m}^{2}(\mathrm{P} \# 6)
\end{aligned}
$$

The above answers reveal that the participants who provided the wrong answers to this question were unaware of the correct relation between $\mathrm{cm}^{2}$ and $\mathrm{m}^{2}$ or unable to build the relation in the right direction.

The $8^{\text {th }}$ question had three sub-questions regarding mass, length, and volume measurement. Accordingly, the participants were expected to identify the relationship between gram and microgram, kilometer and meter, and $\mathrm{dm}^{3}$ and $\mathrm{mm}^{3}$. The difference of this question was that the participants were expected to determine the appropriate unit for the given values.
In the sub-questions of this question, the percentages of the correct answers were $2.7 \%, 78.1 \%$, and $19.2 \%$, respectively. It was seen that in the first sub-question regarding the conversion from gram into microgram, the percentages of wrong answers and no answers were quite high. In the third sub-question regarding the conversion from $\mathrm{dm}^{3}$ into $\mathrm{mm}^{3}$, again the percentage of the wrong answers was quite high $(72.6 \%)$. Below, there are examples of wrong answers to the first and third sub-questions, respectively:

$$
170 \mathrm{~g}=170000000 \mathrm{mg}(\mathrm{P} \# 8)
$$

$1 \mathrm{~m}^{3}=106 \mathrm{~mm}^{3}$, because we multiply it by $10^{6}$ as we go 2 steps down $\left(\mathrm{m}^{3} \mathrm{~cm}^{3} \mathrm{~mm}^{3}\right)(\mathrm{P} \# 19)$

From the above answers, we understand that regarding the first sub-question, participant\#8 was aware that the answer should have been a smaller unit than gram, but (s)he was unable to provide a correct answer as (s)he probably did not know any smaller unit than milligram and/or did not know the correct relation between the units. Moreover, regarding the third subquestion, participant\#19 knew the correct relation between the volume units, but (s)he forgot to put $\mathrm{dm}^{3}$ in the order, so provided a wrong answer.

In the $10^{\text {th }}$ question, the participants were asked to determine the appropriate length unit for an object that they mostly face during their daily life (a pencil in this case). The majority of the participants were able to provide a correct answer to this question (94.5\%). It was seen that only four participants could not make a correct decision about the size of a pencil. Below, there are some examples of the participants' answers:

If the unit was mm, then the length of the pencil would be so small. I mean it would be quite shorter than a standard pencil. Hence, it was more appropriate to use $\mathrm{cm}$ as the unit here $(\mathrm{P} \# 5)$

It was cm because it was equal to a hand span. Meter was too big, mm was too short. Thus, $\mathrm{cm}$ was the most appropriate unit $(\mathrm{P} \# 31)$

We can measure the length of a pencil using a ruler. On rulers, the length units are given in $\mathrm{cm}(\mathrm{P} \# 46)$

My height is $160 \mathrm{~cm}$. Then, $16.5 \mathrm{~cm}$ which is smaller than that would be appropriate for a pencil's length (P\#52)

These answers reveal that the participants were able to make correct estimations through real-life examples through making comparisons and reasoning.

In the $11^{\text {th }}$ question, there were two related sub-questions. Accordingly, the participants were first asked to convert mm into $\mathrm{m}$, and then calculate the cross-section area in $\mathrm{m}^{2}$. Then, in the second sub-question, they were asked to calculate the cross-section area in $\mathrm{mm}^{2}$ and then convert it into $\mathrm{m}^{2}$. In these sub-questions, the percentages of the correct answers were $39.7 \%$ and $19.2 \%$, respectively. From here, it can be suggested that when the participants did the unit conversion between length units first and then calculated the area, their performance was doubled compared to when they calculated the area first and then did the conversion between area units. In both sub-questions, the percentages of the wrong answers were quite high. 
Below is from participant\#31's answers to these sub-questions:

\begin{tabular}{lccc}
\hline $\begin{array}{l}\text { Diameter } \\
(\mathbf{m m})\end{array}$ & $\begin{array}{c}\text { Radius } \\
(\mathbf{m m})\end{array}$ & $\begin{array}{c}\text { Radius } \\
(\mathbf{m})\end{array}$ & Cross-section area $\left(\mathbf{m}^{2}\right)$ \\
\hline 0.27 & 0.135 & $0.135 .10^{-4}$ & $5.10^{-10}$ \\
\hline $\begin{array}{l}\text { Diameter } \\
(\mathbf{m m})\end{array}$ & $\begin{array}{c}\text { Radius } \\
(\mathbf{m m})\end{array}$ & $\begin{array}{c}\text { Cross-section } \\
\text { area }\left(\mathbf{m m}^{2}\right)\end{array}$ & Cross-section area $\left(\mathbf{m}^{2}\right)$ \\
\hline 0.27 & 0.135 & 0.054 & 540 \\
\hline
\end{tabular}

The above answers indicate that this participant was unsuccessful in converting $\mathrm{mm}$ into $\mathrm{m}$ and thus came up with a wrong answer to the first part although her/his calculation for cross-section area was correct. In the second part of the question, although her/his calculations for radius in $\mathrm{mm}$ and cross-section area in $\mathrm{mm}^{2}$ were correct, the participant was unable to convert $\mathrm{mm}^{2}$ into $\mathrm{m}^{2}$.

\section{What are the Prospective Science Teachers' Major Difficulties with Unit Conversion?}

For the second research question, the past three open-ended questions of the measurement test were analyzed $\left(12^{\text {th }}\right.$ $14^{\text {th }}$ questions).

In the $12^{\text {th }}$ question, the participants were asked whether they had difficulty with unit conversion or not. In Table 2, related frequencies and percentages are provided.

As seen from the Table 2, more than half of the participants stated that they had difficulty with unit conversion. Only one of the participants did not have any difficulties. Accordingly, participants responded that:

I do have difficulties. Especially, when I have to decide if I should add or delete zeros from the numbers. ( $\mathrm{P} \# 17)$ I have had difficulties with unit conversion since my childhood. I have never got it right. (P\#20)

I struggle with exponential and negative terms. I don't know all the units. (P\#51)

I definitely have problems with unit conversion. I have difficulty with the units except from basic conversions.

I struggle, because I use them very rarely and I am not used to them. (P\#59)

I have difficulty with the conversion of units such as Gm, because we don't use them daily. I also have difficulty with converting capacity units into volume units. (P\#71) In the $13^{\text {th }}$ question, the participants were asked what was their most difficult question in the measurement test. As a result, the $3^{\text {rd }}$ and the $11^{\text {th }}$ questions were the most difficult questions for the prospective teachers with equal percentages $(48 \%)$. The participants noted they had difficulty with converting

\begin{tabular}{lcc}
\hline $\begin{array}{l}\text { Table 2: The prospective teachers' levels of difficulties } \\
\text { with unit conversion }\end{array}$ & \# \\
\hline Response & 41 & 56.1 \\
\hline Yes & 27 & 37.0 \\
Sometimes & 1 & 1.4 \\
No & 4 & 5.5 \\
\hline No-answer & & \\
\hline
\end{tabular}

gigameter into nanometer as well as converting $\mathrm{mm}$ into $\mathrm{m}$, calculating cross-section area in $\mathrm{mm}^{2}$, and then converting it into $\mathrm{m}^{2}$. The $5^{\text {th }}$ question followed with $36 \%$ while the $7^{\text {th }}$ and $9^{\text {th }}$ questions had similar percentages $(34 \%$ and $32 \%$, respectively). These questions were mainly asking prospective teachers to determine the relation between centigram and dekagram. The other difficult questions for the participants were the $4^{\text {th }}$ and $8^{\text {th }}$ questions $(22 \%$ and $11 \%$, respectively). When their answers to the $13^{\text {th }}$ question were compared to their actual performances in the measurement test, it was seen that the questions they struggled most in the test were $8 \mathrm{a}, 3,4 \mathrm{~b}, 8 \mathrm{c}$, and $11 \mathrm{~b}$, and $9^{\text {th }}$ questions while their perceptions regarding their difficulties were somehow different as explained above.

Finally, in the last question, the participants were asked about the courses that were affected the most by their difficulties with unit conversion. The majority of the participants stated that their difficulties with unit conversion negatively affected their success in their physics class (90\%). Chemistry followed with $41 \%$, then mathematics (15\%) and astronomy (14\%) classes. Below, there are some examples from the participants' responses:

It affects the physics class the most. Sometimes I can't solve the problems in physics class even if I know the way to solve it since I can't do the conversions (P\#13)

It affects my science classes because I have to be able to do the unit conversions in order to reach the correct answers in those classes. I lose it from the beginning when I can't do the conversions ( $\mathrm{P} \# 18)$

It enormously affects my physics and chemistry classes. When I see that the problems require unit conversion, then I pass them right away ( $\mathrm{P} \# 26)$

It affects physics and chemistry classes, and sometimes mathematics. However, mostly I have difficulty in physics classes. When unit conversion comes to the fore, then physics becomes unbelievably difficult for me (P\#50)

We generally use unit conversion in physics, chemistry, and physics lab classes, and as we mostly prefer memorization, we struggle with it while solving problems in those classes (P\#64)

\section{DISCUSSION, IMPLICATIONS, AND CONCLUSION}

The aim of this study was to investigate prospective science teachers' knowledge of and difficulties with the metric unit conversion. Accordingly, whether and how the prospective science teachers can convert metric units and their major difficulties with unit conversion were examined. The results revealed that the unit conversion performance of the prospective science teachers was not satisfying in general, and their major difficulties were related mainly to the conversion from gram into microgram, $\mathrm{mg}$ into $\mathrm{g}, \mathrm{ml}$ into $\mathrm{cm}^{3}, \mathrm{dm}^{3}$ into $\mathrm{mm}^{3}$, gigameter into nanometer, $\mathrm{mm}^{2}$ into $\mathrm{m}^{2}$, and determining the relationship between centigram and dekagram.

The results of the study are in line with several studies in the literature. As stated before, research suggests that students have difficulty with unit conversion within the metric system. For 
example, in Mikula and Heckler's (2013) study, engineering students had difficulty with converting micrograms to kilograms and/or centimeters to nanometers, etc., although they were supposed to have adequate knowledge on unit conversion. The researchers concluded that as these students use metric conversions constantly while solving problems in engineering, their low performance was quite worrisome. Similarly, in the present study, the finding that most of the prospective science teachers had difficulty with converting gigameter into nanometer was somewhat worrisome since these prefixes are often used in today's technology. For example, nanometer is often used in the expression of the atomic scales as well as in the definition of the wavelength of the electromagnetic radiation while gigameter is often used in defining distances in astronomy. From here, it might be deduced that future science teachers have weaknesses regarding the importance and area of usage of these prefixes in the age of technology. To give an example from the participants' explanations, the below quotation provides an insight on how they approach the use of these prefixes:

I don't struggle with the units that we use in our daily lives, but since we don't use them daily and only use them in our courses, I struggle with the units like cg and Gm (P\#64)

In another study by Cebesoy and Yeniterzi (2016), $7^{\text {th }}$-grade students struggled with unit conversion while solving physics problems. In Aydın's (2011) study, science teaching students mathematically struggled with unit conversion in a chemistry course. With similar findings, Birinci and Pirasa (2010) concluded that deficient knowledge of science teaching students related to unit conversion risked their science literacy skills. Gilman (2013) also found that the students had difficulty with unit conversion, no matter the direction of the conversion was. In another study, Hallagan (2013) found that prospective teachers had difficulty with unit conversion problems, especially when they were with different prefixes than that they were used to. Kloosterman's (2012) study findings also revealed that 13-year-old students' performance on unit conversion among metric units showed a decline when compared to their performance on past years. The researcher concluded that the drop on students' performance on conversion among metric units overtime was a big concern since conversion within the metric system is an important issue in an international workplace context.

All these studies in the literature, as well as the present study findings, indicate that many students - no matter what their grade levels are - have a deficient knowledge of unit conversion within the metric system. As Birinci and Pirasa (2010) and Koray et al. (2005) underlined, this deficiency of knowledge of such a fundamental concept carries risk in the development of students' scientific literacy skills. At this point, it might be suggested that students have difficulty with unit conversion as they do not have enough chances to experience unit conversions through real-life problems during their formal education. Sokolowski (2015) points to this deficiency and adds that traditional teaching requires students to memorize the symbols of prefixes. He adds that students do not receive enough help with explicitly identifying and recognizing prefixes in given quantities. At this point, Gilman (2013) suggests educators teach different types of conversions in equal amounts of time and practice estimation more during daily activities. Similarly to Hallagan (2013), DeMeo (2008) made a further suggestion and pointed to the role of instruction on multiple solution methods while solving conversion problems. He suggested that mathematics and science teachers should collaborate on teaching multiple representations, and help students grasp different representations and make connections between them to be able to transfer their knowledge of basic conversions to more complex ones. He warned educators that if teachers did not prepare students conceptually to understand unit conversion within the metric system and flexibly solve conversion problems through multiple solution methods, then their future success in science would be jeopardized.

While it seems important to change the ways to teach unit conversion to students, on the other hand, as in the study by Mikula and Heckler (2013), not every instruction or training helps students perform better even in simple metric conversions. No matter how long they receive instruction on unit conversion throughout their formal education, students still seem to have difficulty with the concept. The researchers explained the possible underlying reason for this deficiency as a conscious choice. Accordingly, when students feel the comfort to just look it up, they do not want to memorize the metric conversions (Mikula and Heckler, 2013). To the best of our knowledge, one possible way to make students feel the need to conceptually learn these concepts might be connecting the concept to real life, and provide them opportunities to experience hands-on activities as much as possible. Especially when basic conversions matter, it is suggested to provide students opportunities with the construction of their own measurement tools, and making several measurements through these tools after making estimations (Sherman, 1997 as cited in Gilman, 2013). Such hands-on experiences are expected to help students better comprehend metric concepts (Sherman, 1997 as cited in Gilman, 2013). Gilman (2013) suggested that if different areas of conversions (linear, volume, and capacity) were not taught equally, then a gap was built among these areas making some of them harder for students than others. Then, not only giving chances to conducting hands-on activities but also spending an equal amount of time in all areas was necessary for students to be successful in unit conversion while doing that it was also important that educators explained the reasoning behind the unit conversions within the metric system (Gilman, 2013). Building connections between the units and daily practices, and asking for estimation might be useful in enhancing students' conceptual understanding of unit conversion.

To conclude, it should be reminded that being one of the fundamental concepts in science, units and unit conversions within the metric system plays an important role in effective and meaningful science learning (Koray et al., 2005). As 
this study's findings revealed, the ability to convert metric units also has an influence on participants' performance on science courses such as physics and chemistry. Thus, understanding teachers', prospective teachers', and/or students' understanding, misconceptions, and difficulties with unit conversion are vital to develop more effective teaching programs for student success. For further research, it is recommended that face-to-face interviews with participants would be useful to better understand their thinking and difficulties regarding unit conversion. Finally, as Hallagan (2013) suggest, examining prospective teachers' use of multiple methods of unit conversion while solving problems within the metric system might be a good start to help their future students.

\section{REFERENCES}

Aydın, A. (2011). Fen Bilgisi ogretmenligi ogrencilerinin bazi matematik kavramlarina yonelik hatalarinin ve bilgi eksiklerinin tespit edilmesi [Identifying Science Teaching students' misconceptions and knowledge deficiencies regarding some mathematical concepts]. BAU Fen Bilimleri Enstitusu Dergisi [BAU Journal of Institute of Science], 13(1), 78-87.

Bagno, E., Berger, H., \& Eylon, B.S. (2008). Meeting the challenge of students' understanding of formulae in high-school physics: A learning tool. Physics Education, 43(1), 75-82.

Birinci, K.K., \& Pirasa, N. (2010). Sinif ogretmenligi adaylarinin mol kavramindaki islem becerilerinin belirlenmesi [Determination of the process skills of the prospective primary teachers' regarding mole concept]. Cukurova University Faculty of Education Journal, 38(3), 150-161.

Blackley, S., \& Howell, J. (2015). A STEM narrative: 15 years in the making. Australian Journal of Teacher Education, 40(7), 102-112.

Butterfield, A., Sutherland, R., \& Molyneux-Hodgson, S. (2011). Learning Conversions in Science: The Case of Vocational Students in the UK. Available from: https://www.journal.alt.ac.uk/index.php/rlt/article/ view/1189/1439. [Last retrieved on 2018 Jun 14].

Cebesoy, U.B., \& Yeniterzi, B. (2016). $7^{\text {th }}$ grade students' mathematical difficulties in force and motion unit. Turkish Journal of Education, 5(1), 18-32.

Chalmers, C., Carter, M.L., Cooper, T., \& Nason, R. (2017). Implementing "big ideas" to advance the teaching and learning of science, technology, engineering, and mathematics (STEM). International Journal of Science and Mathematics Education, 15(1), 25-43.

Cheng, W.L. (1976). An Analysis of the Effectiveness of Alternative Systems Approaches and Instructional Methods for Teaching the Metric System. (Retrospective Theses and Dissertations. Paper 6279). Available from: https://www.lib.dr.iastate. edu/cgi/viewcontent.cgi?referer=https://scholar.google.com .tr/sch.olar?hl=tr\&as_sdt $=0 \% 2 \mathrm{C} 5 \& \mathrm{q}=\mathrm{An}+$ analysis + of + the + effectiveness + of + alternative+systems + approaches + and + instructional + methods + for+teaching + the + metric + system $\& b \operatorname{tnG}=\&$ httpsredir $=1$ $\&$ article $=7278 \&$ context $=$ rtd. [Last retrieved on 2018 Jun 14].

Common Core State Standards (CCSS). (2011). Preparing America's Students for Success. Available from: http://www.corestandards.org/. [Last retrieved on 2018 Jun 14].

Cooke, A., \& Walker, R. (2015). Exploring STEM education through pre-service teacher conceptualisations of mathematics. International Journal of Innovation in Science and Mathematics Education, 23(3), $35-46$.

Çorlu, M.A., \& Çorlu, M.S. (2012). Scientific inquiry based professional development models in teacher education. Educational Sciences: Theory and Practice, 12, 514-521.

Delgado, C., Stevens, S.Y., Shin, N., \& Krajcik, J. (2015). A middle school instructional unit for size and scale contextualized in nanotechnology. Nanotechnology Reviews, 4(1), 51-69.

DeMeo, S. (2008). Multiple Solution Methods for Teaching Science in the Classroom. Boca Raton, FL: Universal Publishers.
Ford, E.N.J., \& Gilbert, Y.V. (2013). Displacement between orders of magnitude method for SI unit conversion. Journal of Chemical Education, 90, 134-136.

Gilman, J. (2013). Have you Met Ric? Student Misconceptions of Metric Conversions and the Difficulties Behind Metric Unit Estimation. (Master's Thesis, State University of New York at Fredonia, New York). Available from: https://www.dspace.sunyconnect.suny.edu/ bitstream/handle/1951/62652/Gilman,\%20Jennifer\%20-\%20Thesis. pdf? sequence $=1 \&$ sa $=$ U\&ei $=$ dDxqU7_UK8KfyASdmICQCw\&ved $=0 \mathrm{C}$ CsQFjAD\&usg=AFQjCNH-51Ba9xctqSzF2AJ1p196YGQPQA. [Last retrieved on 2018 Jun 14].

Greca, I.M., \& de Ataíde, A.R.P. (2017). The influence of epistemic views about the relationship between physics and mathematics in understanding physics concepts and problem solving. In: Greczyło, T., \& Dębowska, E., (Eds.), Key Competences in Physics Teaching and Learning. Chum: Springer International Publishing. pp. 55-64.

Hallagan, J.E. (2013). Preservice mathematics teachers' solutions to problems: Conversions within the metric system. Systemics, Cybernetics and Informatics, 11(7), 15-20.

Harmon, G. (1984). The measurement of information. Information Processing and Management, 20(1-2), 193-198.

Kloosterman, P. (2012). Mathematics Performance of 13-Year Olds in the United States: 1978 to 2004. Philadelphia, PA: Paper Presented at the Annual Meeting of the National Council of Teachers of Mathematics. pp. 25-28.

Koray, O., Özdemir, M., \& Tatar, N. (2005). İlkogretim ogrencilerinin "birimler" hakkinda sahip olduklari kavram yanilgilari: Kutle ve agirlik ornegi primary school students' misconceptions about “units": Example of mass and weight. Illkogretim Online [Elementary Education Online], 4, 24-31.

Kurt, K., \& Pehlivan, M. (2013). Integrated programs for science and mathematics: Review of related literature. International Journal of Education in Mathematics, Science and Technology, 1(2), 116-121.

Lehavi, Y., Bagno, E., Eylon, B.S., Mualem, R., Pospiech, G., Böhm, U., Krey, O., \& Karam, R. (2017). Classroom evidence of teachers' PCK of the interplay of physics and mathematics. In: Greczyło, T., \& Dębowska, E., (Eds.), Key Competences in Physics Teaching and Learning. Vol. 190. Chum: Springer International Publishing. pp. 95-104.

Leroy, N. (1973). Let's use the metric system: A supplement to mathematics K-6. New York State Education Department. Albany: Bureau of Elementary Curriculum Development. (ERIC No. ED086551).

Livy, S., \& Vale, C. (2011). First year pre-service teachers' mathematical content knowledge: Methods of solution to a ratio question. Mathematics Teacher Education and Development, 13(2), 22-43.

Lonning, R.A., \& DeFranco, T.C. (1997). Integration of science and mathematics: A theoretical model. School Science and Mathematics, 97(4), 212-215.

Ludwig, H. (2016). How are the metric system and SI different? Available from: https://www.quora.com/How-are-the-metric-system-and-SIdifferent. [Last retrieved on 2018 Jun 14].

Meltzer, D.E. (2002). The relationship between mathematics preparation and conceptual learning gains in physics: A possible "hidden variable" in diagnostic pretest scores. American Journal of Physics, 70(12), 1259-1268.

Merriam, S.B. (2009). Qualitative Research: A Guide to Design and Implementation. San Francisco, CA: Jossey-Bass.

Mikula, B.D., \& Heckler, A.F. (2013). The Effectiveness of Brief, Spaced Practice on Student Difficulties with Basic and Essential Engineering Skills. In 2013 IEEE Frontiers in Education Conference (FIE). pp. 1059-1065.

Neuendorf, K.A. (2002). The Content Analysis Guidebook. Thousand Oaks, CA: Sage Publications.

Nguyen, D.H. (2011). Facilitating Students' Application of the Integral and the Area Under the Curve Concepts in Physics Problems. (Doctoral dissertation, Kansas State University). Available from: http:// www.krex.k-state.edu/dspace/bitstream/handle/2097/8631/DongHaiNguyen2011.pdf?sequence $=1$. [Last retrieved on 2018 Jun 14].

Oktay, C.E., Sülün, A., \& Sanalan, V. (2014). Ogrenci ve ogretmenlerin fen ve teknoloji dersinin yasamimizdaki surat konusundaki matematik 
becerileri uzerine gorusleri [Opinions of the students and the teachers about science and technology lessons on their mathematical skills of the speed concept in daily lives]. Erzincan Universitesi Fen Bilimleri Enstitusu Dergisi [Erzincan University Journal of Institute of Science], 7(1), 37-55.

Rebmann G., \& Viennot L. (1994). Teaching algebraic coding: Stakes, difficulties and suggestions. American Journal of Physics, 62(8), 723-727.

Redish, E.F. (2005). Problem Solving and the Use of Math in Physics Courses. New Delhi, India: Paper presented at the World View on Physics Education in 2005: Focusing on Change Conference. pp. 21-26.

Redish, E.F. (2017). Analysing the competency of mathematical modelling in physics. In: Greczyło, T., \& Dębowska, E., (Eds.), Key Competences in Physics Teaching and Learning. Chum: Springer International Publishing. pp. 25-40.

Sokolowski, A. (2015). Recognizing prefixes in scientific quantities. The Physics Teacher, 53, 358-359.
Talim Terbiye Kurulu (TTKB). (2017). MEB Müfredat Gelişstirme Süreci. Available from: http://www.mufredat.meb.gov.tr/ProgramDetay. aspx?PID=191. [Last retrieved on 2018 Jun 14].

Thompson, A., \& Taylor, B.N. (2008). The NIST guide for the use of the international system of units (SI). NIST Special Publication 811, 2008 Edition. Available from: https://www.physics.nist.gov/cuu/pdf/sp811. pdf. [Last retrieved on 2018 Jun 14].

Tuminaro, J., \& Redish, E.F. (2007). Elements of a cognitive model of physics problem solving: Epistemic games. Physical Review Special Topics-Physics Education Research, 3(2), 1-22.

Uhden, O., \& Pospiech, G. (2009). Translating between mathematics and physics: Analysis of student's difficulties. In: GIREP-EPEC Conference Frontiers of Physics Education. pp. 26-31.

Uhden, O., Karam, R., Pietrocola, M., \& Pospiech, G. (2012). Modelling mathematical reasoning in physics education. Science and Education, 21(4), 485-506.

\section{APPENDIX}

\begin{tabular}{|c|c|c|c|c|}
\hline \multicolumn{5}{|c|}{ Appendix 1: The measurement test with the main objectives } \\
\hline \# & & Main objectives & Measurement units & The questions \\
\hline 1 & & Converting $\mathrm{cm}$ into $\mathrm{mm}$ & Length & $50 \mathrm{~cm}=\mathrm{mm}$ \\
\hline 2 & & Converting $\mathrm{mm}$ into $\mathrm{km}$ & Length & $450.000 .000 \mathrm{~mm}=\mathrm{km}$ \\
\hline 3 & & Converting $\mathrm{Gm}$ into $\mathrm{nm}$ & Length & $26 \mathrm{Gm}=\mathrm{nm}$ \\
\hline \multirow[t]{2}{*}{4} & a & $\begin{array}{l}\text { Converting } \mathrm{mg} \text { into } \mathrm{g} / \mathrm{ml} \text { into } 1 \text { Calculating } \\
\text { density in } \mathrm{g} / \mathrm{l}\end{array}$ & Mass + Volume & $\begin{array}{l}\text { Calculate the density of an object in } \mathrm{g} / \mathrm{l} \text { having } 50 \mathrm{ml} \text { volume } \\
\text { and } 450 \mathrm{mg} \text { mass. }\end{array}$ \\
\hline & $\mathrm{b}$ & $\begin{array}{l}\text { Converting } \mathrm{mg} \text { into } \mathrm{g} / \mathrm{ml} \text { into } \mathrm{cm}^{3} \text { Calculating } \\
\text { density in } \mathrm{g} / \mathrm{cm}^{3}\end{array}$ & Mass+Volume & $\begin{array}{l}\text { Calculate the density of an object in } \mathrm{g} / \mathrm{cm}^{3} \text { having } 50 \mathrm{ml} \text { volume } \\
\text { and } 450 \mathrm{mg} \text { mass. }\end{array}$ \\
\hline 5 & & Converting cg into dag & Mass & $1000 \mathrm{cg}=\mathrm{dag}$ \\
\hline 6 & & Converting $\mathrm{cm}^{2}$ into $\mathrm{m}^{2}$ & Area & $3200 \mathrm{~cm}^{2}=\mathrm{m}^{2}$ \\
\hline 7 & & Converting dag into cg & Mass & $0.001 \mathrm{dag}=\mathrm{cg}$ \\
\hline \multirow[t]{3}{*}{8} & a & $\begin{array}{l}\text { Identifying the relationship between gram } \\
\text { and microgram }\end{array}$ & Mass & $170 \mathrm{~g}=170.000 .000$ \\
\hline & $\mathrm{b}$ & $\begin{array}{l}\text { Identifying the relationship between } \\
\text { kilometer and meter }\end{array}$ & Length & $5=5000 \mathrm{~m}$ \\
\hline & $\mathrm{c}$ & $\begin{array}{l}\text { Identifying the relationship between } \mathrm{dm}^{3} \text { and } \\
\mathrm{mm}^{3}\end{array}$ & Volume & $1=10^{6} \mathrm{~mm}^{3}$ \\
\hline 9 & & Converting cg into dag & Mass & $1.0 \times 10^{3} \mathrm{cg}=\mathrm{dag}$ \\
\hline 10 & & Estimating the length unit of a pencil & Length & $\begin{array}{l}\text { The approximate length of a standard pencil is } 16.5 \ldots \text { Select the } \\
\text { appropriate unit and explain why you have chosen it. }\end{array}$ \\
\hline \multirow[t]{2}{*}{11} & a & $\begin{array}{l}\text { Converting } \mathrm{mm} \text { into } \mathrm{m} \text { Calculating } \\
\text { cross-section area in } \mathrm{m}^{2}\end{array}$ & Length + Area & $\begin{array}{l}\text { Find the cross-section area of a string with the given radius in } \\
\mathrm{m}^{2} \text {. Start with converting } \mathrm{mm} \text { into } \mathrm{m} \text {, and then calculate the } \\
\text { area. }\end{array}$ \\
\hline & $\mathrm{b}$ & $\begin{array}{l}\text { Calculating cross-section area from } \mathrm{mm} \text { to } \\
\mathrm{mm}^{2} \text { Converting } \mathrm{mm}^{2} \text { into } \mathrm{m}^{2}\end{array}$ & Area & $\begin{array}{l}\text { Find the cross-section area of a string with the given radius in } \\
\mathrm{m}^{2} \text {. Start with calculating the area in } \mathrm{mm}^{2} \text {, and then convert it } \\
\text { into } \mathrm{m}^{2} \text {. }\end{array}$ \\
\hline 12 & & Reflections for in-depth analysis & - & $\begin{array}{l}\text { Do you experience difficulty with unit conversion? Explain } \\
\text { your difficulties. }\end{array}$ \\
\hline 13 & & Reflections for in-depth analysis & - & $\begin{array}{l}\text { Rank the three questions above from the hardest to less hard } \\
\text { that you had the most difficulty with. }\end{array}$ \\
\hline 14 & & Reflections for in-depth analysis & - & $\begin{array}{l}\text { Which classes you think are affected by your difficulties with } \\
\text { unit conversion? How? }\end{array}$ \\
\hline
\end{tabular}

